\title{
The Innovative Countermeasure of Ideological and Political Education for College Students under the Background of Multi-culture
}

\author{
Jijun Wu \\ College of Art and Information Engineering, Dalian Polytechnic University, Dalian, 116400, China \\ 112756788@qq.com
}

Keywords: multi-culture; university students; ideological and political education; innovation countermeasures

\begin{abstract}
Strengthening ideological and political education is an important measure to train builders and successors of the socialist cause. Multi-culture has brought ideological and political education to unprecedented challenges. It has comprehensively understood the profound influence of multi-culture on ideological and political education, explored the new characteristics of ideological and political education under the background of multi-culture, and became important for studying the ideological and political education of college students and improving the effectiveness of ideological and political education content. Guided by relevant theories, this paper expounds the relationship between multi-culture and college students' ideological and political education, analyzes the opportunities, challenges of university students' ideological and political education in the context of multi-culture, and proposes innovative countermeasures for college students' ideological and political education in the context of multi-culture. The reform of ideological and political teaching promotes the overall improvement of college students' ideological and political consciousness.
\end{abstract}

\section{Introduction}

Multi-culture means that as human society becomes more and more complex and information circulation becomes more developed, the renewal and transformation of culture is also accelerating. The development of various cultures faces different opportunities and challenges, and new cultures will emerge in an endless stream. Under the modern and complex social structure, different cultures are inevitably required to serve the development of society. These cultures serve the development of society and create the cultural diversity, that is, multi-culture in the context of complex society. Education is inseparable from the support and influence of the cultural environment. The effective functioning and realization of educational functions cannot be separated from the good cultural and ecological environment. Education is a certain positive means for educators to exert their own positive influence on the mind and spirit of the educators, to make positive changes in the mind and spirit of the educators, to increase their knowledge, to enhance the ability to transform the real society, and to become the social need people. The realization of the purpose of ideological and political education is inseparable from a certain cultural environment support and a certain cultural soil nourishment.

Based on the important theories such as Marxism-Leninism, Mao Zedong Thought, Deng Xiaoping Theory, the important thinking of the "Three Represents" and the Scientific Outlook on Development, this paper studies the practical problems of college students' ideological education under the multi-cultural background, aiming to help teachers improve their ideological and political education. The level promotes the development of students' own quality, provides practical and feasible solutions for college ideological and political education, deepens teaching reform, and promotes the overall improvement of students' ideological and political consciousness. 


\section{Relationship between Multi-culture and Ideological and Political Education of College Students}

Multi-culture and ideological and political education of university students are the relationship of unity and opposition. The two are interconnected and develop together, which is both different and identical. The specific performance is in three aspects:

(1) The diversity between multi-culture and ideological and political education in colleges and universities. First, the emphasis is different. Ideological and political education has strong political nature, which is ideological education restricted by politics, and is a social practice activity, which ideological education and political education interact and infiltrate each other; multi-culture has a strong cultural heritage, pays attention to capacity cultivation, and pays attention to culture. The educational function, from which to take advantage of the factors that contribute to spiritual growth. Second, history continues in different ways. The purpose of ideological and political education for university students is to cultivate the ideology of socialism and communism; multi-culture is closely integrated with real life and can be universally existed in popular ideas and passed down from generation to generation.

(2) The consistency between multi-culture and ideological and political education in colleges and universities. First, the consistency of goal, ideological and political education and the goal of multicultural cultivation are all based on the all-round development of people, promoting the formation of the good morality, establishing harmonious interpersonal and social relationships, and providing internalization for the development of science and technology. Spiritual motivation. Second, the consistency of theoretical foundation, Marxism is the common theoretical basis of ideological and political education and multicultural cultivation. Marxism is not only the theoretical foundation of ideological and political education, but also the highest level and realm of multi-culture. Third, the consistency of content. Both of them promote harmonious coexistence between man and nature, man and society, and between people from the aspects of morality and ideas.

(3) The interactive development of multi-culture and university students' ideological and political education. Multi-culture promotes ideological and political education for university students, and ideological and political education also promotes the development of cultural diversity. In a multicultural society, ideological and political education not only inherits its own culture, but also undertakes functions to digest and absorb foreign culture. On the one hand, the school's ideological and political education has abandoned the traditional culture, created new culture and promoted multicultural development according to the development of the time; on the other hand, ideological and political education has cultivated people with pioneering spirit and traditional culture. It inherits and innovates, integrates tradition with modern culture, creates the new culture that adapts to the development of modern society, and promotes the development and prosperity of multi-culture.

\section{Opportunities on Ideological and Political Education of College Students on the Background of Multi-culture}

As a development trend of contemporary world culture, multi-culture promotes the prosperity of world culture, increases the vitality of national culture, helps eliminate cultural centralism and cultural hegemonism, and brings new opportunities for college students' ideological and political education. In the following aspects:

(1) The content of ideological and political education of college students has expanded continuously under the background of multi-culture. The multicultural social environment has broadened the horizons of university students and greatly enhanced their intellectual and social understanding. Standing at the cultural joint at all times and in all over the world, the attention of university students to ideological and morality has been expanding, and the sensitivity and degree of contact with external ideological and moral phenomena have surpassed any previous time. The 
content of ideological and political education for college students has also expanded due to multiculturalism.

(2) Multi-culture has spawned the innovation of university students' ideological and political education methods. Multi-culture has quietly changed the concept of ideological and political education, exposing the shortcomings of the traditional "indoctrination" and "dictatorial rule" education methods, and spawned a teaching method with modern information technology as the core, and students as the main body and respecting the individuality of students. Respecting the needs of individual diversity of students, adopting flexible and diverse theoretical teaching and practical teaching, and enhancing the effectiveness of ideological and political education for university students.

(3) Multi-culture is conducive to the further improvement of the individual spirit of university students. Human individuals have self-fulfilling needs, and there is no single value and principle in the world. The multicultural environment is conducive to individual development, providing individuals with more choice opportunities and value orientations, choosing the culture that suits their individuality and taste, giving individuals more freedom and the richer spiritual world, as well as more powerful performance and more. Meaningful life exists, making society more dynamic and more stable.

(4) Multi-culture expands the space for ideological and political education of university students. The advent of the multicultural era, especially the development of network culture, the educational environment of colleges and universities, and the ideas and thoughte of students have undergone profound changes. Students have the conditions and the opportunity to contact different cultural ideas and expand the horizons of university students. Facilitating university students' understanding of different regional cultures, historical cultures, social institutional knowledge and different cultural thinking methods is conducive to promoting university students to actively learn ideological and political and expand the space of ideological and political education.

\section{Challenges on Ideological and Political Education of College Students on the Background of Multi-culture}

Multicultural development, impacting mainstream culture, diluting ideology, crowding out elegant culture, dispelling humanistic spirit, objectively forming a "second cultural space" different from mainstream culture, making university students' ideological and political education face new challenges Specifically, it is manifested in the following aspects:

(1) Multi-culture causes the splitting of the spirit and belief of university students. He has doubts and denials about Marxism-Leninism, Mao Zedong Thought and Deng Xiaoping Theory; he is in a state of confusion in culture, loses scientific judgment in cultural choice, hesitates in the process of value selection, and lacks good thinking ability and ability to distinguish; Under the influence of Western thoughts, the steady beliefs of university students have been shaken, and they are prone to instability and diversification, which has brought shock to the spiritual world of students.

(2) The conflict of multiple values is likely to lead to moral misconduct among university students. Multi-culture has established a variety of values for many areas of social life. In the past, some excellent behavioral goals and methods of university students have been disintegrated by multicultural conflicts and social reforms, and they are in a state of incomprehensibility. The ability to judge is in an inextricable dilemma in moral cognition and practice, and it is easy to cause confusion in moral choice, disorder in value orientation, loss of moral evaluation, and loss of moral ideal.

(3) Multi-culture leads to the obvious tendency of individualism among university students. Contemporary university students pay attention to the realization of self-worth, advocating freedom, self-reliance and self-improvement, and to a certain extent, are conducive to achieving self-worth and promoting all-round development. Although they know the important role of society and the collective in personal development, they value social and collective respect and satisfaction to the individual. The value orientation of a few university students is even seriously unbalanced, self-centered, ignoring the needs of society and the collective, individualism. The tendency is more 
serious.

(4) Multi-culture has weakened the pursuit of university students' core values. The culture of decay and behind the time bring challenges to the dissemination and education of core values. The egoism and hedonism of Western bourgeois ideology dispel the educational influence of China's common affluence and impact the appeal of core values such as "patriotism" and "dedication". The bad elements in multiculturalism are not conducive to the education and dissemination of China's core values, and have a negative impact on the ideological and political education of university students.

(5) Multi-culture weakens the subjectivity of university students' ideological and political educators. Under the influence of multi-culture, the amount of information received by students is huge, the values are diverse, the authority and dominance of educators are challenged, and the subjectivity of interaction between educators and educatees is weakened. Under the impetus of mass media, it has broken. The educational model of one-way flow of educational information, even some students have more knowledge information than educators, weakening the subjectivity of university students' ideological and political educators.

\section{Innovation Countermeasures on Ideological and Political Education of College Students on the Background of Multi-culture}

Under the multicultural background, the ideological and political education of university students involves the coordination of related elements such as system, rule, platform and carrier. Through the application of innovative countermeasures, university students are guided to form a new concept of cognition, values and practice in a multicultural context, and promote students to build their own learning and lifestyle, becoming a qualified builder and reliable successor of socialism. The innovative countermeasures for university students' ideological and political education in the context of multi-culture are as follows:

(1) Enrich the content of ideological and political education for university students under the background of multi-culture. Carry forward the traditional Chinese culture, cultivate the national cultural identity of university students, and create the good school culture environment. At the same time, it absorbs the beneficial and universal ideological and cultural achievements in western culture and serves the socialist construction. Adhere to the requirements of dominance and diversity of dialectical unity, and unify the dominance of Marxist world outlook, outlook on life and values, and the diversity of characteristics and requirements of university students. The situation of multicultural coexistence provides materials for university students' ideological and political education, making full use of this historical opportunity, innovating the concept of value education, and expanding the content of ideological and political education in universities that meet the requirements of the time.

(2) Construct the socialist core value system of university students' ideological and political education under the background of multi-culture. The socialist core value system is the essence of socialist advanced culture, the essence of socialist ideology, and determines the development direction of socialism with Chinese characteristics. Under the background of multi-culture, university students' ideological and political education must let the mainstream ideology lead non-mainstream ideology, lead ideological and political education with socialist core value system, and regard socialist core value system as the basic content of ideological and political education. process. Improve the level of Marxist theory of university students, cast the national spirit and the spirit of the time, enhance the ideological realm and moral level of university students, and face the multi-culture with ease.

(3) Expand the theoretical vision of university students' ideological and political education in the context of multi-culture. Strengthen Marxism-Leninism theory, Mao Zedong Thought and Deng Ping theory education, and adhere to Marxism-Leninism, Mao Zedong Thought, Deng Ping Theory and the Scientific Outlook on Development. Innovative education methods expand the theoretical horizons of university students' ideological and political education, making theoretical research a habit and continuously improving the efficiency and effectiveness of ideological and political 
education. Innovative ideological and political education must be based on the objective laws of respecting ideological and political education, and explore the law of the emergence and change of university students' thoughts. In addition to having a certain degree of courage, theoretical expansion must adhere to the principle of seeking truth from facts, presenting true novelty and innovation, and forming unique creative thinking insights.

(4) Update the discourse system of ideological and political education in the context of multi-culture. Language is the cloak of thought, and the vivid and philosophical expression of language is not only directly related to the teaching effect. The discourse system is the medium for achieving the goal of teaching and improving the teaching effect, and is an important task for teaching reform. Under the multi-cultural background, the context of ideological and political education in colleges and universities is very complicated. It is necessary to pay attention to the art of "what to say" and the intensity of "saying how much", but also to pay attention to the technique of "how to say". Ideological and political education workers should communicate with the minds of university students, so that teaching can be based on harmony, the passion of teaching and the enthusiasm of learning can resonate with each other, and the attraction and appeal of ideological and political education will be continuously enhanced.

(5) Enhance the effectiveness of ideological and political education for university students under the background of multi-culture. Respect the subjective status of students, choose scientific educational methods, innovate educational means, and rely on high-quality cultural carriers to enhance the effectiveness of ideological and political education. First, innovate traditional methods and advocate rigorous scientific methods, from a single inculcation model to a two-way communication model. Second, the combination of direct education and indirect education gives full play to the effectiveness of the guidance and extracurricular activities taught in the classroom. Third, play the role of the network carrier, use the network platform to convey social policies, deliver correct value orientation and moral concepts, guide healthy network culture, and enhance immunity against the influence of false thoughts and decadent lifestyles.

(6) Improve the quality of the faculty of ideological and political education in the context of multi-culture. Teachers are the key to ideological and political education. Under the impact of multi-culture, the quality of ideological and political education teachers in colleges and universities has declined drastically. The establishment of high-quality teachers has become an inevitable requirement for the reform of ideological and political education. First, strengthen training, carry out special training and targeted training activities, organize ideological and political education teachers to participate in vocational planning, mental health, employment guidance and student management training; second, strengthen practice, establish the social practice base, and send teachers to the base to participate in the temporary training. Activities such as social practice and study and study have enabled teachers to truly understand how Marxist theory guides practice and how it works, and applies it flexibly to educational and teaching activities.

\section{References}

[1] Y. L. Li, "Analysis of Countermeasures to the Ideological and Political Education In China's Colleges and Universities from the Angle of the Multicultural," Theory Research, vol. 55, no. 12, pp. 362-364, 2013.

[2] J. T. Wang, "Multicultural Perspective-Based Research on College Students' Ideological and Political Education," Journal of Shenyang Jianzhu University(Social Science), vol. 19, no. 4, pp. 416-420, 2017.

[3] S. Q. Liu, "Countermeasures of ideological and political education of college students under the multi cultural background," Journal of Jiamusi Vocational Institute, vol. 33, no. 9, pp. 133-134, 2016. 
[4] $\mathrm{H} . \mathrm{Wu}$, "Education innovation in ideological and political science in universities from the perspective of multi-culture," Theoretical Front in Higher Education, vol. 27, no. 8, pp. 52-55, 2012.

[5] J. Li, "Teaching Reform for the Course of Ideology and Politics in the Multi-cultural Context," Journal of Harbin University, vol. 34, no. 11, pp. 135-137, 2013. 